\title{
The effect of diets containing raw and fermented faba beans on gut functioning and growth performance in young turkeys
}

\author{
A. Drażbo ${ }^{1,3}$, D. Mikulski ${ }^{1}$, J. Jankowski ${ }^{1}$ and Z. Zduńczyk ${ }^{2}$ \\ ${ }^{1}$ University of Warmia and Mazury in Olsztyn, Department of Poultry Science, Oczapowskiego 5, 10-718 Olsztyn, Poland \\ ${ }^{2}$ Institute of Animal Reproduction and Food Research, Polish Academy of Sciences, Tuwima 10, 10-748 Olsztyn, Poland
}

KEY WORDS: turkeys, performance, digestive tract, fermentation, faba beans

Received: $\quad 22$ May 2017

Revised: 29 September 2017

Accepted: 15 February 2018

${ }^{3}$ Corresponding author:

e-mail: aleksandra.drazbo@uwm.edu.pl

\begin{abstract}
The aim of the study was to evaluate the effects of partial replacement of soyabean meal (SBM) with $35 \%$ of raw or fermented faba beans (RFB and FFB, respectively) on the development of the gastrointestinal tract and growth performance in young turkeys. FB were fermented with Lactobacillus plantarum. In comparison with RFB, FFB had similar crude protein content, but lower NDF and higher ADF contents. Partial replacement of SBM with FB seeds led to a decrease in wheat content, and an increase in the contents of highprotein components (by approx. 22 percentage points) and soyabean oil (by 2.5 percentage points) in turkey diets. The dietary inclusion of RFB and FFB did not affect the viscosity of small intestinal digesta. In comparison with the SBM diet, the RFB diet significantly decreased the concentrations of ammonia and butyric acid, reduced the activities of some microbial enzymes in the caecal digesta, but did not affect the concentrations of putrefactive and total short chain fatty acids (SCFAs). In comparison with the RFB diet, the FFB diet did not improve the turkey growth performance, but had a positive impact on fermentation processes in the caeca, which was reflected in an increase in the total concentrations of SCFAs and a decrease in ammonia concentration in the caecal digesta. So, dietary supplementation with $35 \%$ of FB does not compromise the growth performance of turkeys from 1 to 8 weeks of age. Fermentation of FB with Lactobacillus plantarum improves selected parameters of caecal functioning, but does not improve the growth performance of young turkeys.
\end{abstract}

\section{Introduction}

Global legume production is currently on the rise due to the increasing nutritional and economic significance of legume seeds (Chandra-Hioe et al., 2016). Legume seeds have been used primarily in diets for broiler chickens (Moschini et al., 2005; Hejdysz et al., 2016), but also for turkeys (Zduńczyk et al., 2014a; Przywitowski et al., 2016) and laying hens (Drażbo et al., 2014; Zduńczyk et al., 2014b). Faba beans (FB) are among the most extensively researched legume species in Europe, due to their high content of protein (about 26\%) and starch (about 30\%) as well as high concentrations of amino acids, comparable with soyabean meal (SBM) (Fru-Nji et al., 2007). FB (Vicia faba L.) are considered a valuable source of protein, energy and other nutrients in poultry nutrition. However, the presence of antinutritional factors such as tannins, protease inhibitors, oligosaccharides and non-starch polysaccharides (NSP), as well as a low content of sulphur-containing amino acids reduce the nutritional value of $\mathrm{FB}$, and can negatively affect nutrient utilisation and animal performance (Hejdysz et al., 2016). Oligosaccharides 
and NSP are not degraded by digestive enzymes in monogastric animals, and their presence is closely correlated with the viscosity of small intestinal digesta, thus affecting the rate of feed passage and impairing gastrointestinal functioning (Liang, 2000; Jankowski et al., 2009). The presence of antinutritional factors limits the use of raw legumes in poultry diets. Various processing techniques can be employed to lower the levels of antinutritional factors in FB seeds while increasing their protein content (Laudadio et al., 2011).

Fermentation is a simple processing technique that long time ago has been deployed to improve the nutritional value and functional properties of original products (Frias et al., 2008). It has also been widely used to enhance the bioavailability of nutrients (Hotz and Gibson, 2007) and remove undesirable compounds from legumes and other feed ingredients (Mukherjee et al., 2016). The effect of fermentation is determined by the substrate and the nature of the process, nevertheless according to Rozan et al. (1996) fermentation contributes to the degradation of $84 \%$ of carbohydrates, $30 \%$ of lignin and $47 \%$ of total glucosinolates in rapeseed meal. This technique lowers the content of flatulence-causing factors in legumes, increases protein concentration and improves protein digestibility through the hydrolysis of high-molecular-weight proteins into peptides and amino acids (Teng et al., 2012). According to Amadou et al. (2010), fermentation increases trypsin digestibility in vitro and nitrogen solubility under alkaline conditions. In the fermentation process a wide variety of microorganisms, mainly yeasts and fungi, are used. Lactic acid bacteria, including Lactobacilllus, Lactococcus, Streptococcus, Leuconostoc and Pediococcus are also applied due to their unique organoleptic properties (Liu et al., 2011).

In the previous studies it was revealed that fermented soyabeans, soyabean derivatives and rapeseed meal had a positive influence on the growth performance of broiler chickens (Hirabayashi et al., 1998; Feng et al., 2007). However, the effect of fermentation on the nutritional value of FB remains insufficiently investigated. There is no available information on the efficacy of fermented FB in turkeys, or on the effects of fermented legumes on gut function in poultry.

Therefore, the objective of this study was to determine the effect of raw and fermented FB in the diets of young turkeys (up to 8 weeks of age) on the growth performance and the physiological response of the gastrointestinal tract.

\section{Material and methods}

The study protocol was approved by the Local Ethics Committee for Animal Experiments in Olsztyn. The animals were maintained accordingly to the guidelines comparable to EU Directive 2010/63/EU.

\section{Faba beans}

Certified dark-coloured FB seeds var. Bobas were used in the experiment (COBORU, 2011). Before bacterial fermentation, FB seeds were crushed using the H-790 Crushing Roller Mill (Rolmako, Wrzesnia, Poland), and were mixed with water containing the Lactobacillus plantarum strain LMG 6907 in a 1:1 ratio. The concentration of lactic acid bacteria in wet seeds was $2.4 \times 10^{7} \mathrm{CFU} \cdot \mathrm{g}^{-1}$. Fermentation was carried out at $30-32{ }^{\circ} \mathrm{C}$ for $36 \mathrm{~h}$, in sealed containers, until $\mathrm{pH} 4.0$ was achieved. Wet seeds contained $28.2 \mathrm{~g} \cdot \mathrm{kg}^{-1}$ of total organic acids (including $77.1 \%$ of lactic acid, $14.0 \%$ of acetic acid and $7.9 \%$ of butyric acid), and had low ethanol content $\left(0.71 \mathrm{~g} \cdot \mathrm{kg}^{-1}\right)$, which indicates that fermentation was conducted properly. After fermentation, the seeds were dried at $45{ }^{\circ} \mathrm{C}$ for $24 \mathrm{~h}$ on perforated metal sheets with blowing air.

\section{Birds, housing and diets}

In total, 288 day-old female Hybrid Converter turkeys, obtained from a local commercial hatchery, were randomly allocated to 3 dietary treatments with 6 replicates per treatment and 16 birds per replicate. Turkeys were raised in pens on litter until 8 weeks of age. The initial body weight (BW) of 1-day-old poults was $63 \pm 3 \mathrm{~g}$. Indoor temperature was $32{ }^{\circ} \mathrm{C}$ at the beginning of the experiment, and $22{ }^{\circ} \mathrm{C}$ at the end of week 8 . The adopted lighting program was: $24 \mathrm{~h}$ light with an intensity of $100 \mathrm{~lx}$ in the first $72 \mathrm{~h}$, followed by $18 \mathrm{~h}$ light per day until day 14 , and $16 \mathrm{~h}$ light per day until the end of the trial. Light intensity was reduced to $5 \mathrm{~lx}$ between days 3 and 7 , and it was gradually increased to $15 \mathrm{~lx}$ as of week 5 .

During each of two feeding phases (weeks 1-4 and 5-8), birds were ad libitum fed isoenergetic diets containing 27.0 and $25.0 \%$ of CP, respectively, according to nutrient requirements for turkeys (Hybrid Turkeys, 2014). A control wheat-SBM-based diet (C) and diets containing 35\% of raw or fermented FB seeds (RFB and FFB, respectively) as a substitute for SBM, wheat and other ingredients were formulated in each feeding stage. All diets contained similar amounts of major amino acids (including lysine, methionine with cysteine, threonine), minerals (including calcium and available phosphorus), and 
Table 1. Ingredient composition and nutrient content of control diet $(C)$ and experimental diets containing raw or fermented faba bean seeds (RFB and FFB, respectively) fed to turkeys from 1 to 8 week of age, \%, as-fed basis unless indicated otherwise

\begin{tabular}{|c|c|c|c|c|c|c|}
\hline \multirow{2}{*}{ Indices } & \multicolumn{3}{|c|}{ Weeks 1-4 } & \multicolumn{3}{|c|}{ Weeks 5-8 } \\
\hline & C & RFB & FFB & $\mathrm{C}$ & RFB & FFB \\
\hline \multicolumn{7}{|l|}{ Ingredients } \\
\hline wheat & 51.54 & 26.09 & 26.09 & 50.23 & 24.79 & 24.79 \\
\hline soyabean meal & 37.77 & 25.83 & 25.83 & 41.37 & 29.43 & 29.43 \\
\hline faba bean & - & 35.00 & 35.00 & - & 35.00 & 35.00 \\
\hline potato protein & 4.00 & 4.00 & 4.00 & - & - & - \\
\hline soyabean oil & 1.48 & 3.98 & 3.98 & 3.64 & 6.14 & 6.14 \\
\hline limestone & 1.75 & 1.78 & 1.80 & 1.57 & 1.61 & 1.61 \\
\hline monocalcium phosphate & 1.79 & 1.80 & 1.80 & 1.54 & 1.53 & 1.53 \\
\hline $\mathrm{NaCl}$ & 0.18 & 0.18 & 0.18 & 0.18 & 0.18 & 0.18 \\
\hline sodium sulphate & 0.15 & 0.15 & 0.15 & 0.15 & 0.15 & 0.15 \\
\hline DL-methionine ${ }^{1}$ & 0.33 & 0.41 & 0.41 & 0.29 & 0.38 & 0.38 \\
\hline L-lysine $\mathrm{HCL}^{2}$ & 0.43 & 0.23 & 0.23 & 0.42 & 0.22 & 0.22 \\
\hline L-threonine ${ }^{2}$ & 0.08 & 0.05 & 0.05 & 0.11 & 0.08 & 0.08 \\
\hline vitamin-mineral premix ${ }^{3}$ & 0.50 & 0.50 & 0.50 & 0.50 & 0.50 & 0.50 \\
\hline \multicolumn{7}{|l|}{ Analysed nutrients } \\
\hline crude protein & 26.5 & 27.1 & 27.1 & 24.1 & 24.2 & 24.2 \\
\hline crude fat & 2.72 & 4.16 & 5.05 & 4.49 & 5.39 & 5.52 \\
\hline neutral detergent fibre & 9.64 & 11.85 & 9.04 & 11.09 & 13.52 & 11.42 \\
\hline acid detergent fibre & 5.85 & 7.83 & 7.35 & 4.87 & 8.32 & 7.93 \\
\hline \multicolumn{7}{|l|}{ Calculated nutrients } \\
\hline metabolizable energy, $\mathrm{kcal} \cdot \mathrm{kg}^{-1}$ & 2750 & 2750 & 2750 & 2850 & 2850 & 2850 \\
\hline crude fibre & 3.21 & 4.77 & 4.77 & 3.32 & 4.89 & 4.89 \\
\hline lysine & 1.74 & 1.74 & 1.74 & 1.60 & 1.60 & 1.60 \\
\hline methionine + cysteine & 1.13 & 1.13 & 1.13 & 1.04 & 1.04 & 1.04 \\
\hline threonine & 1.06 & 1.06 & 1.06 & 0.98 & 0.98 & 0.98 \\
\hline calcium & 1.20 & 1.20 & 1.20 & 1.10 & 1.10 & 1.10 \\
\hline non-phytate phosphorus & 0.55 & 0.55 & 0.55 & 0.50 & 0.50 & 0.50 \\
\hline sodium & 0.14 & 0.14 & 0.14 & 0.14 & 0.14 & 0.14 \\
\hline
\end{tabular}

${ }^{1} 990 \mathrm{~g}$ methionine $\cdot \mathrm{kg}^{-1}$ (MetAMINO ${ }^{\circledR}$, Evonik Degussa GmbH, Essen, Germany); ${ }^{2} 780 \mathrm{~g} \cdot \mathrm{kg}^{-1}$ lysine and $985 \mathrm{~g} \cdot \mathrm{kg}^{-1}$ threonine (Ajinomoto Eurolysine S.A.S, Amiens, France); ${ }^{3}$ provided per $\mathrm{kg}$ of feed (feeding period: weeks $0-4$ and 5-8, respectively): $\mathrm{mg}$ : retinol 3.78 and 3.38 , cholecalciferol 0.12 and 0.10 , a-tocopheryl acetate 100 and 90 , vit. $\mathrm{K}_{3} 5.8$ and 5.6 , thamine 5.4 and 4.7 , riboflavin 8.4 and 7.5 pyridoxine 6.4 and 5.6, cobalamin 0.032 and 0.028 , biotin 0.32 and 0.28 , pantothenic acid 28 and 24, nicotinic acid 84 and 75 , folic acid 3.2 and 2.8 , Fe 64 and 60 , Mn 120 and 112, Zn 103 and 88, Cu 23 and 19, I 3.2 and 2.8, Se 0.30 and 0.28, choline chloride 400 and 376

vitamins (Table 1). Before inclusion into diets, RFB and FFB with hulls were ground to pass through a 4-mm sieve in a hammer mill (Jesma Company, Sprout Matador, Denmark). Complete diets were pelleted at $65^{\circ} \mathrm{C}$ using the same pelleting machine (Jesma Company, Sprout Matador, Denmark) in the Agrocentrum feed mill (Kaleczyn, Poland). Starter diets were offered as crumbles whereas grower diets (weeks 5-8) were prepared as 3-mm pellets.

\section{Sample collection}

At the end of each 4-week period, body weights (BW) of turkeys and feed intake were recorded, and each pen was considered an experimental unit. Body weight gain (BWG), daily feed intake (DFI) and feed conversion ratio (FCR) were calculated for each group. Mortality rates, including their causes, were recorded daily, and the body weights of dead birds were used to adjust average BWG, DFI and FCR. At the end of the experiment, at 56 day of age, 8 representative birds per group were slaughtered by cervical dislocation to collect the test material.

Segments of the digestive tract (small intestine and caeca) were removed, emptied and weighed; digesta samples were collected, caeca were flushed with water, blotted on filter paper and weighed. The ileum was defined as the segment from Meckel's diverticulum to the ileo-caecal junction. After euthanasia (about $20 \mathrm{~min}$ ), $\mathrm{pH}$ was measured in the digesta collected from each segment using a microelectrode and a pH-ion meter (model 301, Hanna Instruments, Vila do Conde, Portugal).The collected 
samples of the ileal (middle, $1 / 3$ section of ileum) and caecal digesta were used for the analysis of dry matter (DM), ammonia and short chain fatty acids (SCFAs). The remaining portion of caecal digesta was transferred to test tubes and stored at $-70{ }^{\circ} \mathrm{C}$ until needed.

\section{Chemical analysis}

Representative samples of RFB and FFB were analysed in duplicate for DM (method 934.01), crude protein $(\mathrm{CP}, \mathrm{N} \times 6.25$ : method 976.05), ether extract (EE: method 920.39), ash (method 942.05), crude fibre (CF: method 978.10), neutral detergent fibre (NDF: method 2002.04) and acid detergent fibre (ADF: method 989.03), as described by AOAC International (2005). The contents of NDF and ADF were determined using an Ankom fibre analyser (Ankom Technology, Macedon, NY, USA). Gross energy (GE) was determined in RFB and FFB with the use of a Parr Adiabatic Oxygen Bomb Calorimeter (Werke C2000, IKA, Staufen, Germany). The organic acid composition and ethanol content of FB after fermentation were determined by high-performance liquid chromatography (Shimadzu, Kyoto, Japan) using the method proposed by Kostulak-Zielińska and Potkański (2001).

For digesta viscosity measurements, samples of the small intestinal contents $\left(6 \mathrm{~cm}^{3}\right)$ were collected, mixed on a vortex mixer and centrifuged at $7211 \mathrm{~g}$ for $10 \mathrm{~min}$ at $21^{\circ} \mathrm{C}$. The supernatant $(0.5 \mathrm{ml})$ was placed in a Brookfield LVDV-II+ cone-plate rotational viscometer (CP40; Brookfield Engineering Laboratories Inc., Stoughton, MA, USA) and viscosity was measured at a fixed temperature of $39^{\circ} \mathrm{C}$ and a shear rate of 60 per min. Ammonia $\left(\mathrm{NH}_{3}\right)$ was determined by micro-diffusion analysis in Conway's dishes (Hofirek and Haas, 2001) and SCFAs were analysed by gas chromatography (Shimadzu GC-2010, Kyoto, Japan) equipped with a capillary column (SGE, BP21, $30 \mathrm{~m} \times 0.53 \mathrm{~mm}$, SGE Europe Ltd., Kiln Farm Milton Keynes, UK). Samples ( $0.2 \mathrm{~g})$ were mixed with $0.2 \mathrm{ml}$ of formic acid, diluted with deionised water and centrifuged at $7211 \mathrm{~g}$ for $10 \mathrm{~min}$. The supernatant was loaded onto a capillary column (SGEBP21, $30 \mathrm{~m} \times 0.53 \mathrm{~mm}$ ) using an on-column injector. The initial oven temperature was $85^{\circ} \mathrm{C}$, it was raised to $180{ }^{\circ} \mathrm{C}$ by $8{ }^{\circ} \mathrm{C} \cdot \mathrm{min}^{-1}$ and held for $3 \mathrm{~min}$. The temperatures of the flame ionisation detector and the injection port were $180^{\circ} \mathrm{C}$ and $85^{\circ} \mathrm{C}$, respectively. The sample volume for GC analysis was $1 \mu 1$.

The activities of bacterial enzymes $(\alpha-$ and $\beta$-glucosidase, $\alpha$ - and $\beta$-galactosidase, $\beta$-glucuronidase, $\alpha$-arabinopyranosidase, $\alpha$-arabinofuranosidase $\beta$-xylosidase, cellobiosidase) released into the caecal environment were measured as the rate of $p$ - or $o$-nitrophenol release from their respective nitrophenylglucosides. The reaction mixture contained $0.3 \mathrm{ml}$ of a substrate solution $(5 \mathrm{mM})$ and $0.2 \mathrm{ml}$ of a $1: 10$ $(\mathrm{v} / \mathrm{v})$ dilution of the caecal sample in $100 \mathrm{mM}$ phosphate buffer $(\mathrm{pH} 7.0)$ after centrifugation at $7211 \mathrm{~g}$ for $15 \mathrm{~min}$. Incubation was carried out at $39^{\circ} \mathrm{C}$, and $p$-nitrophenol was quantified at $400 \mathrm{~nm}$ and at $420 \mathrm{~nm}(o-$ nitrophenol concentration) after the addition of $2.5 \mathrm{ml}$ of $0.25 \mathrm{M}$ cold sodium carbonate. Enzyme activity was expressed as $\mu \mathrm{mol}$ of the product formed per $h$ per $g$ of digesta. The above procedure applies to the extracellular activities of bacterial enzymes released from bacterial cells into the gastrointestinal environment (Juśkiewicz et al., 2011).

\section{Statistical analysis}

The results of the experiment were verified by one-way ANOVA, and significant differences between groups were determined by Duncan's multiple range test. Data variability was expressed as a pooled standard error of the mean (SEM). The differences were considered significant at $P \leq 0.05$, and the values $0.05<P<0.10$ were considered as a near-significant trend. The software package version 10 (StatSoft Inc., 2011) was used for statistical calculations.

\section{Results}

\section{The effect of partial replacement of SBM with RFB}

In comparison with SBM, RFB had three-fold lower fat content, nearly two-fold lower protein content and two-fold higher NSP content determined as NDF and ADF (Table 2). In SBM, the content of NDF and ADF was almost two-fold lower. In comparison with SBM, RFB had higher gross energy content (18.5 vs $18.2 \mathrm{MJ} \cdot \mathrm{kg}^{-1}$ ) and lower crude ash content ( 2.87 vs $6.47 \%)$.

Table 2. Analysed chemical composition of soyabean meal (SBM), raw faba bean (RFB) and fermented faba bean (FFB) seeds

\begin{tabular}{lccc}
\hline Indices & SBM & RFB & FFB \\
\hline Dry matter (DM), \% & 90.9 & 86.8 & 87.1 \\
DM basis, \% & & & \\
$\quad$ crude protein & 50.6 & 27.4 & 28.2 \\
$\quad$ crude fat & 2.85 & 0.84 & 1.26 \\
ash & 6.47 & 2.87 & 3.16 \\
neutral detergent fibre & 9.61 & 18.7 & 17.9 \\
acid detergent fibre & 6.41 & 10.9 & 12.3 \\
gross energy, $\mathrm{MJ} \cdot \mathrm{kg}^{-1}$ & 18.2 & 18.5 & 18.7 \\
\hline
\end{tabular}


In comparison with the control diet (C), the RFB diet was characterised by similar concentrations of $\mathrm{CP}$ and major amino acids (lysine, methionine with cysteine and threonine), and a higher content of NDF and ADF (Table 1). Diets containing FB seeds had more crude fat because their metabolizable energy content was adjusted by the addition of soyabean oil.

The dietary inclusion of RFB as a partial substitute for SBM and wheat numerically changed the basic parameters of small intestinal and caecal function, but only ceacal digesta ammonia was significantly affected (Table 3 ). Turkeys fed the RFB diet were characterised by lower ammonia levels in the caecal digesta $(P=0.001)$. In addition, the RFB diet contributed to higher weight of the small intestine, a lower $\mathrm{pH}$ of intestinal digesta and a lower DM content of caecal digesta, with $P$-value in the range of $0.061-0.071$. No significant differences were found in the weights of caecal tissue and caecal digesta, or the $\mathrm{pH}$ of caecal digesta between turkeys fed C and RFB diets.
The inclusion of $35 \%$ of RFB into turkey diets had no influence on the growth performance parameters of birds, including BWG, DFI and FCR (all $P>0.05$; Table 5). During the performance trial, one turkey died in the control group. None of the turkeys in the RFB treatment died during the experiment.

\section{The effect of replacing RFB with FFB}

FB seeds subjected to fermentation and drying had similar CP content, slightly lower NDF content and higher ADF, as compared with RFB (Table 2).

In comparison with the RFB diets, the FFB diets had lower NDF content (9.04 vs $11.9 \%$ for starter diets and 11.4 vs $13.5 \%$ for grower diets) whereas minor differences in ADF content were found between RFB and FFB diets (Table 1).

No significant differences in gut function parameters were observed between turkeys fed RFB and FFB diets (Table 3). In comparison with the RFB diet, the FFB diet significantly reduced the activities of selected enzymes in the caecal

Table 3. Physicochemical properties of ileal and caecal digesta in turkeys fed control diet (C) and diets containing 35\% of raw faba bean (RFB) or fermented faba bean (FFB) seeds ${ }^{1}$ at 8 week of age

\begin{tabular}{|c|c|c|c|c|c|}
\hline \multirow{2}{*}{ Indices } & \multicolumn{3}{|c|}{ Treatment } & \multirow{2}{*}{ SEM } & \multirow{2}{*}{$P$-value } \\
\hline & $\mathrm{C}$ & RFB & FFB & & \\
\hline \multicolumn{6}{|l|}{ Small intestinal parameters } \\
\hline weight including digesta, $\mathrm{g} \cdot \mathrm{kg}^{-1} \mathrm{BW}$ & 33.8 & 40.2 & 37.1 & 1.135 & 0.061 \\
\hline digesta DM, \% & 17.8 & 18.7 & 17.2 & 0.332 & 0.209 \\
\hline digesta viscosity, $\mathrm{mPa} \cdot \mathrm{s}$ & 2.14 & 1.75 & 1.63 & 0.112 & 0.159 \\
\hline digesta $\mathrm{pH}$ & 6.29 & 5.63 & 5.55 & 0.145 & 0.071 \\
\hline \multicolumn{6}{|l|}{ Caecal parameters } \\
\hline tissue weight, $\mathrm{g} \cdot \mathrm{kg}^{-1} \mathrm{BW}$ & 4.38 & 4.52 & 4.69 & 0.094 & 0.433 \\
\hline digesta weight, $\mathrm{g} \cdot \mathrm{kg}^{-1} \mathrm{BW}$ & 6.99 & 9.14 & 6.43 & 0.563 & 0.114 \\
\hline digesta DM, \% & 11.7 & 9.45 & 9.23 & 0.480 & 0.064 \\
\hline ammonia, $\mathrm{mg} \cdot \mathrm{g}^{-1}$ & $0.118^{\mathrm{a}}$ & $0.054^{b}$ & $0.064^{b}$ & 0.008 & 0.001 \\
\hline digesta $\mathrm{pH}$ & 6.30 & 6.49 & 6.54 & 0.077 & 0.439 \\
\hline
\end{tabular}

${ }^{1}$ data are the means of 8 birds per treatment group; ab - means without common superscripts within the same row are significantly different at $P \leq 0.05$

In comparison with the $\mathrm{C}$ diet, the RFB diet significantly reduced the activities of $\beta$-glucosidase and $\beta$-xylosidase, whereas the activities of other enzymes of caecal microflora, including $\beta$-glucuronidase, $\alpha$-arabinofuranosidase, $\alpha$-arabinopyranosidase and cellobiosidase, were similar in both groups (Table 4). In the RFB group, the concentration of butyric acid was lower $(P=0.007)$, whereas the concentrations of the remaining acids and total SCFAs were similar to those found in the $\mathrm{C}$ group. No significant differences in putrefactive SCFA concentrations were noted between the groups, but the share of butyrate in the total SCFA pool was significantly lower in the RFB group. microflora: $\alpha$-galactosidase, $\alpha$-arabinofuranosidase, $\alpha$-arabino-pyranosidase and cellobiosidase (Table 4). The activities of the remaining enzymes, including $\beta$-glucuronidase, were comparable in both groups.

No significant differences were found in the concentrations of most SCFAs in the caecal digesta of turkeys fed RFB and FFB diets, except for the levels of butyric acid and iso-butyric acid, which were significantly higher in the FFB group (Table 4). Numerical differences in the concentrations of individual acids, which were greatest in the case of acetic acid and butyric acid, resulted in significantly higher total SCFAs concentration in the FFB group, relative to the RFB group. Increased concentration of 
Table 4. Microbial enzyme activity and concentrations of short chain fatty acids (SCFAs) in the caecal digesta of turkeys fed control diet (C) and diets containing $35 \%$ of raw faba bean (RFB) or fermented faba bean (FFB) seeds ${ }^{1}$

\begin{tabular}{|c|c|c|c|c|c|}
\hline \multirow{2}{*}{ Indices } & \multicolumn{3}{|c|}{ Treatment } & \multirow{2}{*}{ SEM } & \multirow{2}{*}{$P$-value } \\
\hline & $\mathrm{C}$ & RFB & FFB & & \\
\hline \multicolumn{6}{|l|}{ Enzyme activity, $\mathrm{mmol} \cdot \mathrm{h}^{-1} \cdot \mathrm{g}^{-1}$} \\
\hline a-glucosidase & 12.5 & 11.8 & 8.85 & 0.919 & 0.234 \\
\hline$\beta$-glucosidase & $1.64^{\mathrm{a}}$ & $0.98^{b}$ & $0.61^{b}$ & 0.142 & 0.005 \\
\hline a-galactosidase & $9.11^{\mathrm{a}}$ & $8.30^{\mathrm{a}}$ & $3.51^{b}$ & 0.881 & 0.012 \\
\hline$\beta$-galactosidase & 20.5 & 12.9 & 19.7 & 3.276 & 0.600 \\
\hline$\beta$-glucuronidase & 6.41 & 7.10 & 3.95 & 0.939 & 0.374 \\
\hline$\beta$-xylosidase & $2.09^{\mathrm{a}}$ & $0.57^{\mathrm{b}}$ & $0.38^{b}$ & 0.290 & 0.023 \\
\hline a-arabinofuranosidase & $0.63^{\mathrm{a}}$ & $0.74^{\mathrm{a}}$ & $0.19^{b}$ & 0.069 & 0.001 \\
\hline a-arabinopyranosidase & $0.70^{\mathrm{a}}$ & $0.57^{\mathrm{a}}$ & $0.24^{b}$ & 0.056 & 0.001 \\
\hline cellobiosidase & $0.78^{\mathrm{a}}$ & $0.64^{\mathrm{a}}$ & $0.27^{\mathrm{b}}$ & 0.060 & 0.001 \\
\hline \multicolumn{6}{|c|}{ SCFA concentrations, $\mu \mathrm{mol} \cdot \mathrm{g}^{-1}$} \\
\hline acetic acid (C2) & $71.5^{\mathrm{b}}$ & $78.8^{\mathrm{ab}}$ & $88.3^{\mathrm{a}}$ & 2.491 & 0.014 \\
\hline propionic acid (C3) & $4.62^{b}$ & $6.34^{\mathrm{ab}}$ & $8.81^{a}$ & 0.594 & 0.009 \\
\hline iso-butyric acid (C4i) & $0.46^{b}$ & $0.37^{b}$ & $0.81^{a}$ & 0.069 & 0.013 \\
\hline butyric acid (C4) & $20.5^{\mathrm{a}}$ & $13.7^{b}$ & $20.9^{a}$ & 1.137 & 0.007 \\
\hline iso-valeric acid (C5i) & 0.44 & 1.02 & 0.716 & 0.228 & 0.605 \\
\hline valeric acid (C5) & 0.78 & 0.65 & 1.03 & 0.076 & 0.108 \\
\hline putrefactive SCFAs ${ }^{2}$ & 1.69 & 2.03 & 2.56 & 0.236 & 0.333 \\
\hline total SCFAs & $98.3^{b}$ & $100.9^{b}$ & $120.6^{a}$ & 3.017 & 0.001 \\
\hline \multicolumn{6}{|l|}{ SCFA profile, $\%$ of total } \\
\hline $\mathrm{C} 2$ & 74.8 & 77.8 & 73.3 & 1.041 & 0.098 \\
\hline $\mathrm{C} 3$ & 4.77 & 6.28 & 7.29 & 0.486 & 0.100 \\
\hline C4 & $20.7^{a}$ & $13.7^{\mathrm{b}}$ & $17.3^{\mathrm{ab}}$ & 0.951 & 0.006 \\
\hline
\end{tabular}

${ }^{1}$ data are the means of 8 birds per treatment group; ${ }^{2}$ putrefactive SCFAs - the sum of iso-butyric, iso-valeric and valeric acid; ab - means without common superscripts in the same row are significantly different at $P \leq 0.05$.

Table 5. Growth performance of turkeys fed control diet (C) and diets containing $35 \%$ of raw faba bean (RFB) or fermented faba bean (FFB) seeds ${ }^{1}$

\begin{tabular}{|c|c|c|c|c|c|}
\hline \multirow{2}{*}{ Indices } & \multicolumn{3}{|c|}{ Treatment } & \multirow{2}{*}{ SEM } & \multirow{2}{*}{$P$-value } \\
\hline & $\mathrm{C}$ & RFB & FFB & & \\
\hline \multicolumn{6}{|c|}{ Body weight, $\mathrm{kg} \cdot$ bird $^{-1}$} \\
\hline week 4 of age & 1.19 & 1.19 & 1.20 & 0.010 & 0.777 \\
\hline 8 of age & 4.06 & 4.05 & 4.16 & 0.041 & 0.460 \\
\hline \multicolumn{6}{|c|}{ Body weight gain, $\mathrm{kg} \cdot$ bird $^{-1}$} \\
\hline weeks 1 to 4 & 1.12 & 1.13 & 1.14 & 0.010 & 0.777 \\
\hline 5 to 8 & 2.87 & 2.86 & 2.96 & 0.036 & 0.487 \\
\hline 1 to 8 & 3.99 & 3.99 & 4.10 & 0.041 & 0.460 \\
\hline \multicolumn{6}{|c|}{ Daily feed intake, $g \cdot$ bird $^{-1}$} \\
\hline weeks 1 to 4 & 56.2 & 56.8 & 56.0 & 0.620 & 0.883 \\
\hline 4 to 8 & 203 & 193 & 197 & 3.826 & 0.590 \\
\hline 1 to 8 & 126 & 123 & 125 & 1.445 & 0.761 \\
\hline \multicolumn{6}{|c|}{ Feed conversion ratio, $\mathrm{kg} \cdot \mathrm{kg}^{-1}$} \\
\hline weeks 1 to 4 & 1.41 & 1.41 & 1.38 & 0.009 & 0.315 \\
\hline 4 to 8 & 1.80 & 1.80 & 1.81 & 0.008 & 0.926 \\
\hline 1 to 8 & 1.69 & 1.69 & 1.69 & 0.005 & 0.989 \\
\hline \multicolumn{6}{|l|}{ Mortality, birds } \\
\hline weeks 1 to 8 & 1 & 0 & 1 & ND & ND \\
\hline
\end{tabular}

${ }^{1}$ data represent mean values of 6 replicates with 16 birds per treatment; ND - not determined

iso-butyric acid did not lead to higher concentrations of total putrefactive SCFAs in the FFB group, whereas increased concentration of butyric acid eliminated significant differences in the share of butyrate in the total SCFA pool between turkeys fed the $\mathrm{C}$ diet vs the RFB diet. 
FFB used as a substitute for RFB in turkey diets had no influence on the growth performance parameters of turkeys, including BWG, DFI and FCR (all $P>0.05$; Table 5). During the performance trial, one turkey died in the FFB group, similarly to $\mathrm{C}$ group, and mortality rates were not related to any specific dietary treatment.

\section{Discussion}

\section{The effect of partial replacement of SBM with RFB}

It is assumed that due to lower CP content, the replacement of SBM with FB results in an up to $50 \%$ increase in the total content of high-protein components in chicken diets (Nalle et al., 2010). In our experiment, the inclusion of $35 \%$ of FB in turkey diets decreased SBM content by approximately 12 percentage points, wheat content by approximately 25 percentage points and soyabean oil content by 2.5 percentage points.

The content and composition of dietary fibre play an important role in gastrointestinal tract functioning in poultry (Choct et al., 2010). In our experiment, the dietary inclusion of FB seeds increased $\mathrm{NDF}$ and ADF concentrations in turkey diets, but it did not affect the basic parameters of gut function, such as the weight, DM content and $\mathrm{pH}$ of small intestinal and caecal digesta.

Surprisingly, lower concentrations of caecal ammonia noted in RFB and FFB turkeys did not contribute to the desired drop in the $\mathrm{pH}$ of digesta. It is well known that a more acidified large intestinal environment promotes the proliferation of more desirable bacterial species (Zdunczyk et al., 2013). The acidity of caecal digesta is dependent on many different factors, including SCFA and ammonia concentrations as well as the basic buffering capacity of intestinal digesta. It has been reported that in other caecal fermenters, namely rabbits, basic buffering capacity and SCFA concentrations are variables of paramount importance, whereas ammonia levels are only slightly positively related to the caecal $\mathrm{pH}$ value (De Blas et al., 1999). It seems that in the present study, basic buffering capacity was strong enough to maintain similar $\mathrm{pH}$ values in all treatments despite significant differences in SCFA and ammonia concentrations among groups.

The use of RFB in the diet, as a partial substitute for SBM, did not increase the activity of $\beta$-glucuronidase which is considered an indicator of adverse changes in the gut microbiota. It is assumed that the activity of $\beta$-glucuronidase increases with increasing counts of Escherichia coli and Clostridi$u m$ in the intestinal digesta (Beaud et al., 2005).

In the present experiment, partial replacement of SBM with RFB lowered almost four-fold the activity of microbial $\beta$-xylosidase in the caecal digesta. This was probably due to the simultaneous reduction in the wheat content of the RFB diet. The activities of other enzymes of caecal microflora, including $\alpha$-arabinofuranosidase, $\alpha$-arabinopyranosidase and cellobiosidase, were similar in both groups. No increase was noted in SCFA concentrations in the caecal contents, whereas the share of butyric acid in the total SCFAs pool decreased.

A previous study (Helsper et al., 1996) demonstrated that high tannin content is a factor limiting the use of FB seeds in poultry diets. Tannins reduce feed intake, nitrogen digestibility and dietary energy utilisation in poultry. More recent experiments revealed that diets containing $20-30 \%$ of seeds of modern FB varieties had no adverse effect on the growth performance of broiler chickens (Moschini et al., 2005; Gous, 2011) and older turkeys (Przywitowski et al., 2016). In our study, the inclusion of RFB into turkey diets at $35 \%$ did not compromise the growth performance of young birds aged 1 to 8 weeks.

\section{The effect of replacing RFB with FFB}

It is shown that the protein content of legumes can be increased by fermentation (Rozan et al., 1996; Hu et al., 2016). According to Mukherjee et al. (2016), an increase in protein and fat contents may be partially attributed to a decrease in carbohydrate content during fermentation since microorganisms can utilise the substrate as carbon and energy sources to produce microbial protein. Other studies demonstrated that fermentation significantly increases the content of small-size peptides in SBM as long chained proteins are broken down (Hirabayashi et al., 1998). Some microbial strains can secrete protease which converts large-size proteins into small-size proteins. This may change the concentrations of selected amino acids and the amino acid profile of proteins (Frias et al., 2008). In the present experiment, the fermentation process neither increased the protein content of FB seeds nor influenced (via possible changes in the amino acid profile) the growth rate of turkeys.

It is also shown that the fermentation process lowers the concentration of crude fibre (Hu et al., 2016), as a result of decreasing the content of lignin and other indigestible polyphenolic components (Rozan et al., 1996). In our study, fermentation decreased NDF content by approximately 2 percentage points as compared with RFB, i.e. to the level noted in the control diet. Simultaneously, there was no decrease in ADF 
levels in fermented FB seeds, indicating that hemicellulose was not utilised in the fermentation process.

Hemicelluloses contain molecules of xylose, galactose, glucose and mannose linked by $\beta$-glycoside bonds, forming xylan, galactan, glucomannan and arabinoxylan found in wheat grain (Bjergegaard et al., 1997). In comparison with cellulose, hemicelluloses are more readily hydrolysed by enzymes produced by gut microbiota. Moreover, the fermentation made FB oligosaccharides and NSPs more available for caecal microbiota, thus a lower amount of enzymes was sufficient to digest those components or a greater proportion of bacterial enzymes were faster depleted due to increased availability of substrates for bacteria. This could partially explain why in this study increased caecal SCFA concentrations and lower bacterial enzymatic activity were simultaneously observed in the FFB group.

Tannins present in FB seeds could be another factor inhibiting the activity of gut microbiota. According to other authors (Doblado et al., 2003; El-Moghazy et al., 2011), bacterial fermentation decreases the content of tannins and other antinutritional compounds in faba beans and other legume seeds. In the present experiment, enhanced enzymatic activity of caecal microbiota was not observed, which indicates that the increase in SCFA concentrations in the caecal digesta of turkeys fed FFB resulted from increased amounts of substrate (including hemicelluloses) in the digesta and the synthesis of SCFAs, mostly acetate and butyrate, during fermentation.

SCFAs, in particular butyrate, as the end products of fermentation of non-digestible carbohydrates, play a very important role in the proliferation of epithelial cells and maintenance of their integrity (Quigley, 2011). The products of microbial fermentation of nondigestible carbohydrates to SCFAs supply additional energy in the amount of $2.8 \mathrm{~kJ} \cdot \mathrm{g}^{-1}$ of NSP, which means that NSP contribute approximately $3.5 \%$ of metabolizable energy in poultry (Jamroz et al., 2002). In this study, $35 \%$ of FFB increased SCFA concentrations in the caecal digesta, but the growth performance of turkeys fed FFB was similar to that noted in groups fed RFB and C diets.

\section{Conclusions}

Dietary supplementation with $35 \%$ of faba beans, as a substitute for approximately 12 percentage points of soyabean meal and 25 percentage points of ground wheat, does not compromise the growth performance of young turkeys at 1 to 8 weeks of age, and decreases the concentrations of ammonia and butyrate in the caecal digesta. The use of fermented faba beans does not improve the growth performance of turkeys, but exerts a beneficial influence on fermentation processes in the caeca, which is reflected in the increase in total concentrations of short chain fatty acids, including butyric acid, and a decrease in ammonia concentration in the caecal digesta.

\section{Acknowledgements}

This study was carried out within research project No. 505.037.07 'Improvement of native plant protein feeds, their production, trade turnover and utilization in animal feed mixtures', funded by the Polish Ministry of Agriculture and Rural Development.

\section{References}

Amadou I., Amza T., Foh M.B.K., Kamara M.T., Le G.-W., 2010. Influence of Lactobacillus plantarum Lp6 fermentation on the functional properties of soybean protein meal. Emir. J. Food Agric. 22, 456-465, https://doi.org/10.9755/ejfa.v22i6.4663

AOAC International, 2005. Official Methods of Analysis of AOAC International. $18^{\text {th }}$ Edition. Gaithersburg, MD (USA)

Beaud D., Tailliez P., Anba-Mondolon J., 2005. Genetic characterization of the $\beta$-glucuronidase enzyme from a human intestinal bacterium, Ruminococcus gnavus. Microbiology 151, 2323-2330, https://doi.org/10.1099/mic.0.27712-0

Bjergegaard Ch., Sørensen H., Sørensen S., 1997. Dietary fibres - important part of high quality food and feeds. J. Anim. Feed Sci. 6, 145-161, https://doi.org/10.22358/jafs/69513/1997

Chandra-Hioe M.V., Wong Ch.H.M., Arcot J., 2016. The potential use of fermented chickpea and faba bean flour as food ingredients. Plant Foods Hum. Nutr. 71, 90-95, https://doi.org/10.1007/ s11130-016-0532-y

Choct M., Dersjant-Li Y., McLeish J., Peisker M., 2010. Soy oligosaccharides and soluble non-starch polysaccharides: a review of digestion, nutritive and anti-nutritive effects in pigs and poultry. Asian-Australas. J. Anim. Sci. 23, 1386-1398, https://doi. org/10.5713/ajas.2010.90222

COBORU, 2011. Descriptive Register of Varieties. Part 2 (in Polish). Słupia Wielka (Poland)

De Blas C., García J., Carabaño R., 1999. Role of fibre in rabbit diets. a review. Ann. Zootech. 48, 3-13, https://doi.org/10.1051/animres:19990101

Doblado R., Frias J., Muñoz R., Vidal-Valverde C., 2003. Fermentation of Vigna sinensis var. carilla flours by natural microflora and Lactobacillus species. J. Food Protect. 66, 2313-2320, https://doi.org/10.4315/0362-028X-66.12.2313

Drażbo A., Mikulski D., Zduńczyk Z., Szmatowicz B., Rutkowski A., Jankowski J., 2014. Fatty acid composition, physicochemical and sensory properties of eggs from laying hens fed diets containing blue lupine seeds. Eur. Poult. Sci. 78, 1-14, https:// doi.org/10.1399/eps.2014.61

El-Moghazy G.M., Sakr D.M., Abd El Ghafar N.M., 2011. Effect of fermentation of faba bean (Vicia faba) on its nutritive and sensory properties. J. Food Dairy Sci. 2, 237-250 
Feng J., Liu X., Xu Z.R., Liu Y.Y., Lu Y.P., 2007. Effects of Aspergillus oryzae 3.042 fermented soybean meal on growth performance and plasma biochemical parameters in broilers. Anim. Feed Sci. Technol. 134, 235-242, https://doi.org/10.1016/j. anifeedsci.2006.08.018

Frias J., Song Y.S., Martínez-Villaluenga C., De Mejia E.G., VidalValverde C., 2008. Immunoreactivity and amino acid content of fermented soybean products. J. Agric. Food Chem. 56, 99-105, https://doi.org/10.1021/jf072177j

Fru-Nji F., Niess E., Pfeffer E., 2007. Effect of graded replacement of soybean meal by faba beans (Vicia faba L.) or field peas (Pisum sativum L.) in rations for laying hens on egg production and quality. J. Poult. Sci. 44, 34-41, https://doi.org/10.2141/ jpsa.44.34

Gous R.M., 2011. Evaluation of faba bean (Vicia faba cv. Fiord) as a protein source for broilers. S. Afr. J. Anim. Sci. 41, 71-78, https://doi.org/10.4314/sajas.v41i2.71009

Hejdysz M., Kaczmarek S.A., Rutkowski A., 2016. Extrusion cooking improves the metabolisable energy of faba beans and the amino acid digestibility in broilers. Anim. Feed Sci. Technol. 212, 100-111, https://doi.org/10.1016/j.anifeedsci.2015.12.008

Helsper J.P.F.G., van Loon Y.P.J., Kwakkel R.P., van Norel A., van der Poel A.F.B., 1996. Growth of broiler chicks fed diets containing tannin-free and tannin-containing near-isogenic lines of faba bean (Vicia faba L.). J. Agric. Food Chem. 44, 1070-1075, https://doi.org/10.1021/jf950484w

Hirabayashi M., Matsui T., Yano H., Nakajima T., 1998. Fermentation of soybean meal with Aspergillus usamii reduces phosphorus excretion in chicks. Poult. Sci. 77, 552-556, https://doi. org/10.1093/ps/77.4.552

Hofírek B., Haas D., 2001. Comparative studies of ruminal fluid collected by stomach tube or by puncture of the caudoventral ruminal sac. Acta Vet. Brno 70, 27-33, https://doi.org/10.2754/ avb200170010027

Hotz C., Gibson R.S., 2007. Traditional food-processing and preparation practices to enhancing the bioavailability of micronutrients in plant-based diets. J. Nutr. 137, 1097-1100, https://doi. org/10.1093/jn/137.4.1097

Hu Y., Wang Y., Li A., Wang Z., Zhang X., Yun T, Quu L., Yin Y., 2016. Effect of fermented rapeseed meal on antioxidant functions, serum biochemical parameters and intestinal morphology in broilers. Food Agric. Immunol. 27, 182-193, https://doi.org/10 .1080/09540105.2015.1079592

Hybrid Turkey, 2014. Nutrient Guidelines (accessed 10.08.16) http:// www.resources.hybridturkeys.com/nutrition/commercialguidelines

Jamroz D., Jakobsen K., Bach Knudsen K.E., Wiliczkiewicz A., Orda J., 2002. Digestibility and energy value of non-starch polysaccharides in young chickens, ducks and geese, fed diets containing high amounts of barley. Comp. Biochem. Physiol. a Mol. Integr. Physiol. 131, 657-668, https://doi.org/10.1016/ S1095-6433(01)00517-7

Jankowski J., Juskiewicz J., Gulewicz K., Lecewicz A., Slominski B.A., Zdunczyk Z., 2009. The effect of diets containing soybean meal, soybean protein concentrate, and soybean protein isolate of different oligosaccharide content on growth performance and gut function of young turkeys. Poult. Sci. 88 , 2132-2140, https://doi.org/10.3382/ps.2009-00066

Juśkiewicz J., Zduńczyk Z., Żary-Sikorska E., Król B., Milala J., Jurgoński A., 2011. Effect of dietary polyphenolic fraction of chicory root, peel, seed and leaf extracts on caecal fermentation and blood parameters in rats fed diets containing prebiotic fructans. Br. J. Nutr. 105, 710-720, https://doi.org/10.1017/ S0007114510004344
Kostulak-Zielińska M., Potkański A., 2001. Quality of baled grass-clover silages ensiled with chemical additives. Chemical composition. Ann. Anim. Sci. 1, 153-165

Laudadio V., Ceci E., Tufarelli V., 2011. Productive traits and meat fatty acid profile of broiler chickens fed diets containing micronized fava beans (Vicia faba L. var. minor) as the main protein source. J. Appl. Poult. Res. 20, 12-20, https://doi. org/10.3382/japr.2010-00173

Liang D., 2000. Effect of enzyme supplementation on the nutritive value of canola meal for broilers chickens. Master of Science Thesis. University of Manitoba. Winnipeg (Canada)

Liu S.-n., Han Y., Zhou Z.J., 2011. Lactic acid bacteria in traditional fermented Chinese foods. Food Res. Int. 44, 643-651, https:// doi.org/10.1016/j.foodres.2010.12.034

Moschini M., Masoero F., Prandini A., Fusconi G., Morlacchini M., Piva G., 2005. Raw pea (Pisum sativum), raw faba bean (Vicia faba var. minor) and raw lupin (Lupinus albus var. multitalia) as alternative protein sources in broiler diets. Ital. J. Anim. Sci. 4, 59-69, https://doi.org/10.4081/ijas.2005.59

Mukherjee R., Chakraborty R., Abhishek D., 2016. Role of fermentation in improving nutritional quality of soybean meal - a review. Asian-Australas. J. Anim. Sci. 29, 1523-1529, https:// doi.org/10.5713/ajas.15.0627

Nalle C.L., Ravindran V., Ravindran G., 2010. Nutritional value of faba bean (Vicia faba L.) for broiler: Apparent metabolisable energy, ileal amino acid digestibility and production performance. Anim. Feed Sci. Technol. 156, 104-111, https://doi. org/10.1016/j.anifeedsci.2010.01.010

Przywitowski M., Mikulski D., Zdunczyk Z., Rogiewicz A., Jankowski J., 2016. The effect of dietary high-tannin and low-tannin faba bean (Vicia faba L.) on the growth performance, carcass traits and breast meat characteristic of finisher turkeys. Anim. Feed Sci. Technol. 221, 124-136, https://doi.org/10.1016/j.anifeedsci.2016.08.027

Quigley E.M.M., 2011. Microflora modulation of motility. J. Neurogastroenterol. Motil. 17, 140-147, https://doi.org/10.5056/ jnm.2011.17.2.140

Rozan P., Villaum C., Bau H.M., Schwertz A., Nicolas J.P., Méjean L., 1996. Detoxication of rapeseed meal by Rhizopus Oligosporus sp-T3: a first step towards rapeseed protein concentrate. Int. J. Food Sci. Technol. 31, 85-90, https://doi.org/10.1111/ j.1365-2621.1996.17-315.x

StatSoft Inc., 2011. Statistica (Data Analysis Software System). Version 10. http:// www.statsoft.com

Teng D., Gao M., Yang Y., Liu B., Tian Z., Wang J., 2012. Bio-modification of soybean meal with Bacillus subtilis or Aspergillus oryzae. Biocatal. Agric. Biotechnol. 1, 32-38, https://doi. org/10.1016/j.bcab.2011.08.005

Zduńczyk Z., Jankowski J. Mikulski D., Mikulska M., Lamparski G., Slominski B.A., Juśkiewicz J., 2014a. Growth performance, gastrointestinal function and meat quality in growing-finishing turkeys fed diets with different levels of yellow lupine ( $L$. IUteus) seeds. Arch. Anim. Nutr. 68, 211-226, https://doi.org/10 $.1080 / 1745039 X .2014 .920642$

Zdunczyk Z., Jankowski J., Mikulski D., Przybylska-Gornowicz B., Sosnowska E., Juskiewicz J., 2013. Gastrointestinal morphology and function in turkeys fed diets diluted with whole grain wheat. Poult. Sci. 92, 1799-1811, https://doi.org/10.3382/ ps.2012-02482

Zdunczyk Z., Jankowski J., Rutkowski A., Sosnowska E., Drazbo A., Zdunczyk P., Juskiewicz J., 2014b. The composition of enzymatic activity of gut microbiota in laying hens fed diets supplemented with blue lupine seeds. Anim. Feed Sci. Technol. 191, 57-66, https://doi.org/10.1016/j.anifeedsci.2014.01.016 